\title{
Mangrove Forest Utilization for Sustainable Livelihood through Community-Based Ecotourism in Kao Village of North Halmahera District
}

\author{
Yerik Afrianto Singgalen \\ Tourism Department, Faculty of Business Administration and Communication Science, Atma Jaya Catholic University of \\ Indonesia, Jakarta, Indonesia 12930
}

Received March 4, 2019/Accepted July 13, 2020

\begin{abstract}
This article aims to describe the mangrove forest utilization for sustainable livelihood through a community-based ecotourism approach. This research conduct in Kao Village, North Halmahera District of Indonesia. This study was done in a qualitative method using a life-history approach. The data was collected through in-depth interviews, observation, and document study. The data were analyzed using a triangulation method to obtain credible information. These research findings show that cultural value, known as Higaro was able to mobilize the capability to access resources such as natural and social capital. In its development, assimilation and acculturation caused changes in livelihood structure. In addition, The mining sector's existence in the Kao community custom area had the potential to limit access to natural and social capital due to ecological loss. However, the mining sector could mobilize human and physical capital through Social Performance programs in the education sector and infrastructure development. The adverse effects of the mining sector to the environment had become such a stimulus for the Kao Village community to adopt an environmentally friendly development approach that had economic value and was able to improve the community welfare. Thus, the Kao Village community managed to maintain and utilize the mangrove forest using a community-based ecotourism approach to endurance livelihood sustainability. These results could be developed into recommendations for regional policymakers, especially in the rural areas, to mobilize the capability of local community access to capitals through the tourism sector to maintain livelihood sustainability.
\end{abstract}

Keywords: mangrove forest utilization, community-based ecotourism, rural development, hibualamo

*Correspondence author, email: yerik.afrianto@atmajaya.ac.id

\section{Introduction}

The discussion of this article is more dominant in the social aspects of the community through case studies of the utilization of mangrove forest resources as an ecotourism approach for sustainable livelihood. The theoretical contribution of this research explicitly to the perspective of sustainable livelihoods. The research methodology used is a qualitative method with a case study approach. Research related to the impact of utilizing forest resources on local livelihood has been conducted previously in a different context, strategy, and method (Astuti et al., 2020). Social and cultural structure distinguishes the capability of access to natural capital has been proven through the case of community forests in Bogor (Sukwika et al., 2020). The dominance of culture in the utilization of natural resources can be an effective strategy in achieving ecotourism sustainability through the case Bali Aga of Mount Lesung Region (Haribawa et al., 2020). Theoretically, previous research findings of livelihood sustainability illustrate the correlation between social and cultural aspects to the capability of access to social and natural capital. Therefore, the structure of livelihood change becomes an interesting issue as well as gaps in the literature that are important for further research. Based on the empirical significance, it is essential to examine the social and cultural aspects of Kao community through the experienced of cultural and structural modification in accessing natural capital and social capital. This article also outlines the role of policies and institutions in mobilizing the Kao people access capabilities to other forms of capital, such as physical capital, human capital, and financial capital.

Development in Eastern Indonesia should not depend on natural resources such as copper, gold, or nickel processed by the mining industry, but also forest resources and culture managed by the tourism industry. There are contradictory paradigms on the development of the mining and tourism industry where previous researchers showed that there were environmental damages as a result of mining activities (Yudhistira et al., 2011). On the other hand, the tourism 
industry relies on ecological sustainability as valuable resources (Ballantyne \& Pickering, 2012; Banerjee, 2012; López-Bonilla \& López-Bonilla, 2014). Otherwise, the decision to optimize resources, whether the mining or tourism industry, should be the government's responsibility as the authority.

The decentralization policy supports the authority to optimize regional development as one of the national system efficiency strategies supporting development effectiveness to achieve equality (Sulistiowati, 2014). Nevertheless, the power to regulate decentralized system-based natural resource management approaches is inseparable from various problems, such as social conflicts due to struggles over land (Paradhisa, 2012) as a result of local political enforcement (Haboddin, 2012). In the context of North Halmahera District development, the district government supports the mining industry to increase regional investment by issuing policies (Hakim, 2014; Risal et al., 2017). The orientation of the district government is more focused on economic development through the development of the mining sector. In fact, the environmental damage due to mining activities will simultaneously affect socio-cultural aspects and even the regional economy (Irawan, 2013; Aziz, 2014; Kustiana et al., 2016; Mutiara, 2018; Nuraeni, 2018). Thus, it is necessary to conduct an in-depth study on the impact of the existence and activities of the mining industry on community livelihoods in North Halmahera Regency.

This article is a development of the research results on sustainable livelihoods in Limau Village, Galela Utara District, North Halmahera Regency. Base on that research result, the ritual capital, was able to mobilize the capability of customary community access to natural and social capital as primary resources for rural development as well as to support sustainable livelihoods (Singgalen et al., 2019). However, the resource availability in the village community settlements and the context of vulnerability influencing their livelihood sustainability varies greatly, even in the same research area. For this reason, this study offers an idea to describe the utilization of forest mangrove for sustainable livelihood through community-based ecotourism in Kao Village, Kao Sub-District, North Halmahera District, North Maluku Province, Indonesia.

The sustainable livelihoods approach is a community strategy to overcome various contexts of vulnerability to maintain livelihood resources by utilizing resources that consist of five forms of capital such as human capital, social capital, natural capital, physical capital and financial capital (Stern et al., 2012). The livelihood strategy is related to management or the process of combining the availability of livelihood assets. Several approaches to maintain livelihoods are intensification, extensification, diversification, and migration. (Anani, 1999). Besides, the livelihood strategies can also be seen based on the household socioeconomic status, such as consolidation and accumulation aspects (White, 1991). Furthermore, sustainable livelihood strategies can also utilize natural and other resources (Ellis, 1998). Besides, each previous researcher has a different emphasis, either in the context of vulnerability, resource availability, policies and institutions, and even the capability of access to resources as a form of capital (Oishi et al., 1979; Ashley \& Carney, 1999; Chambers \& Conway, 1992; Solesbury, 2003).
This shows that their paradigm on sustainable livelihoods is very broad, complex, and dynamic, considering the geographical and topographic contexts in each region.

In the context of development, policies and institutions also play an essential role in the mobility of community access to resources. It determines the capability of accumulating capital to access other forms of capital. Therefore, the researcher uses a perspective by Robert John Haylock Chambers and Richard Gordon Conway in describing the context of community livelihood in Kao Village, Kao District, North Halmahera Regency, North Maluku Province, Indonesia. The context of community livelihood in Kao Village shows a different mobility process than the others in Indonesia (Leinbach \& Watkins, 1998; Régnier et al., 2008; Eilenberg \& Wadley, 2009; Rist., 2010; Wijayanti et al., 2016). In general, the mobility of Kao village community access to natural and social capital is supported by traditions in a local culture known as Hibualamo. This implies that the community can utilize natural resources, both forest, and oceans, for their livelihood sustainability. Meanwhile, the tradition in Hibualamo culture becomes such a social glue that fosters mutual trust, forming wider social networks through shared norms (Ancok, 2003; Syahra, 2003; Kusumastuti, 2015; Brata, 2016). In 1999 and 2000, debates and land struggles led to social conflicts (tribal warfare) in the traditional territory of the Kao Village community (Safi, 2017) due to the entry of the mining industry. This shows that in terms of policies and institutions, the regional development policymakers support the optimization of natural resources through the mining sector to operate around the Kao Village common area. As a result, it limits the capability of community access to natural capital when the mining industry dominates land ownership, and land productivity decreases due to polluted water sources (Simbolon et al., 2010; Husen, 2011). Further, unequal workforce recruitment of local communities has also led to conflict and social segregation, although the strengthening of Hibualamo cultural values has been carried out to encourage peace situation in North Halmahera District (Rozi, 2006). This underlines that the policies and institutions can also limit the capability of community access to the intensification of natural and social capital to access other forms of capital.

Natural resource management by the mining sector is very vulnerable to environmental damage (Risal et al., 2017; Nuraeni, 2018) beneficial for the regional economy (Irawan, 2013; Aziz, 2014). The development of sustainable development issues becomes a benchmark for the local government to adopt a development approach that is able to balance economic, socio-cultural, and environmental benefits (Fauzi \& Oxtavianus, 2014). The tourism sector is one approach that is able to increase the country's foreign exchange and regional income through the service industry. The decentralization provides the authority and discretion for the regional government of the North Halmahera Regency to establish a development approach (Sasana, 2016). In its development, the local government - as the development policymaker in North Halmahera Regency starts to optimize natural and cultural resources through the tourism sector. 


\section{Methods}

This study was done in a qualitative method using a case study approach. It was done by considering aspects of coherence researcher correspondence in describing the research results, which are expected to contribute to the literature on development. The scope of this study focuses on the case of mangrove forest utilization for sustainable livelihood through community-based ecotourism in Kao Village, Kao Sub-District, North Halmahera Regency, North Maluku Province. The research location can be seen in the following Figure 1.

Figure 1 visualizes the research location in the form of a map that limits the discussion context concerning the topic of the study. There were several reasons to choose Kao Village as the research location, for example: first, the local community known as Hoana Towiliko had a tradition in managing their forest and marine resources, making to work as farmers and fishers were common and became their main livelihood; second, the existence of mining companies in the common area of Hoana Pagu, Hoana Modole, and Hoana Towiliko had become such a stimulus for social conflicts and caused shifts in the local community livelihood; third, the Kao Village community were aware of the impact of the mining industry activities on the environmental damage. Therefore the mangrove forests were developed based on the community-based ecotourism concept; fourth, the local government also supported the community empowerment program in developing the ecotourism in Kao Village. This research contains relevant background on the empirical and theoretical context. Contextually, the shifts in the Kao Village community livelihoods could be seen from the perspective of sustainable livelihoods.

Relevant background on the empirical and theoretical context used to generate critical ideas on rural development. Especially on sustainable livelihoods issues (Chambers \& Conway, 1992; Ellis, 1998; Ashley \& Carney, 1999; Solesbury, 2003) The context of community livelihoods in Kao Village was influenced by the development orientation, whose policy and institutions were determined by the public and private sector. The modification of the Kao Village community livelihoods depended on the capability of access to natural, social, human, financial, and physical capital. The accumulation of capitals can support the livelihoods of the Kao community integrated with the orientation of village government development programs. This showed that this study might contribute the ideas based on the findings through descriptions on the modification of Kao Village community livelihood, which was not only determined by the capability of access to capitals but also on the probability of development orientation determination, which was dependent on the Kao Village community. Therefore, the researcher argued that the orientation of rural and regional development was not always determined institutionally or based on the policy made by the public and private sectors. The capital access capability and the accumulation of various capitals also determined the development

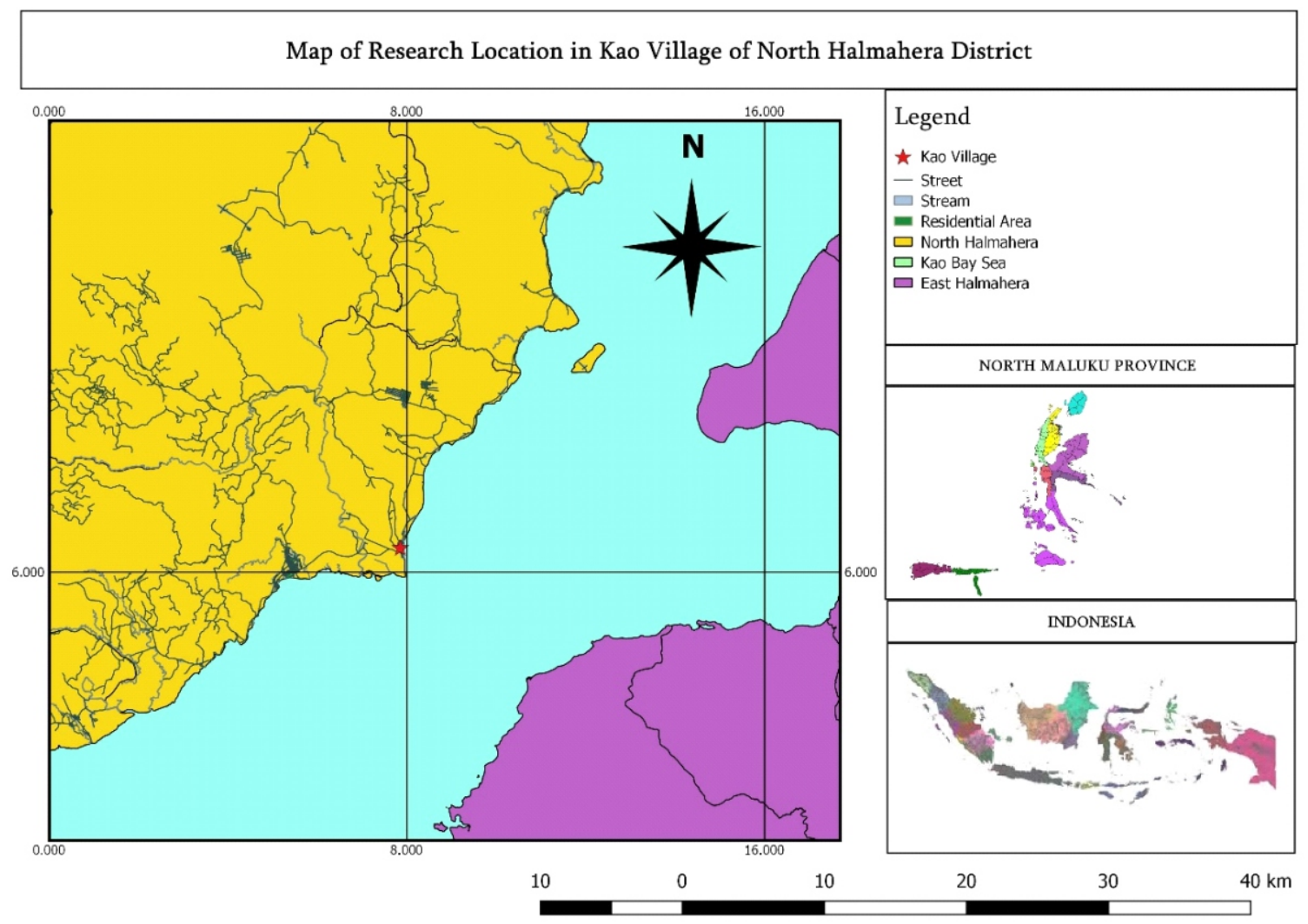

Source: Digitization of research location map using QGIS application 2.18.4

Figure 1 Research location in Kao Village, North Halmahera District. 
orientation, which based on the community.

Data collection process Data collection began in January-December, 2019. The distance and travel time to Kao VIllage using land transportation takes 60 minutes from Tobelo City. The cultural approach is used to obtain information from community groups and obtain recommendations for key informant candidates. The key informants were selected based on several criteria such as considerations on their place of birth, length of stay in Kao Village, activeness in participating in the village development programs, and local cultural activities, understanding, and experience related to the history and culture of the Kao Village community. These criteria helped the researcher to maintain the coherence of information sources obtained that supported the scientific arguments. Besides, the researcher also observed the key informant's activities and the social, economic, and environmental conditions in Kao Village. To obtain valid information, the researcher used in-depth interviews, observation, and document study techniques. The in-depth interview technique involved several key informants who had professional backgrounds and positions in the village and regional government level. Key-informants involved the head of villages, such as Taufick Max as the Head of Kao Village, Melki Laranga as the Head of Kao Sub-District, Kifli Tukang as the Head of Towiliko Tribe (Sangaji Kao). Other key-informants were Hansend Peter Lasa as the representation of the Social Performance Department in PT Nusa Halmahera Minerals, Eddy Papilaya as academician and practitioners in human development for sustainable agriculture, Maria Adya as the local people who work in PT NHM, Holi Yoyano as a local entrepreneur. Based on the agreement between the researcher and the key informant, the identity of farmers and fishers will not be published in this article but only gives initial character. Farmers involved in this research are AL, BM, DB, GN. MK. Fishers involved in this research are RE, $\mathrm{SH}, \mathrm{SB}, \mathrm{YH}, \mathrm{YE}$. Meanwhile, the document study also used to guarantee the validity of the information obtained.

Data analysis process To process the findings into objective scientific studies, the researcher used the triangulation technique. The process of clarifying the validity of information was carried out by emphasizing the alignment of all the data obtained from the in-depth interviews, observation, and document study. Further, the data was linked or compared with the results of previous studies to produce constructive ideas in criticizing the trajectory of the modification of the Kao Village community livelihoods that were mobilized institutionally and in the policy by the public and private sector. Thus, the results of this study might contribute theoretically to the expert's framework in the field of development and sustainable livelihoods, as well as to contribute practically to the development of policies and institutions that able to encourage the Kao Village community livelihood sustainability.

\section{Results and Discussion}

The existence of mangrove forests as a habitat for various animals is a gift for the sustainability of the Kao Community livelihoods. Kao settlements are located in the coastal region as well as in the River Basin of Ake Kao. The location of the Kao settlements is very strategic because it is close to the mangrove forest area, as presented in Figure 2.

Figure 2 shows the strategic location of Kao villagers that supports the sustainability of livelihoods. Since the beginning of living in the coastal area, people have easily accessed the food supplies by fishing or hunting freshwater

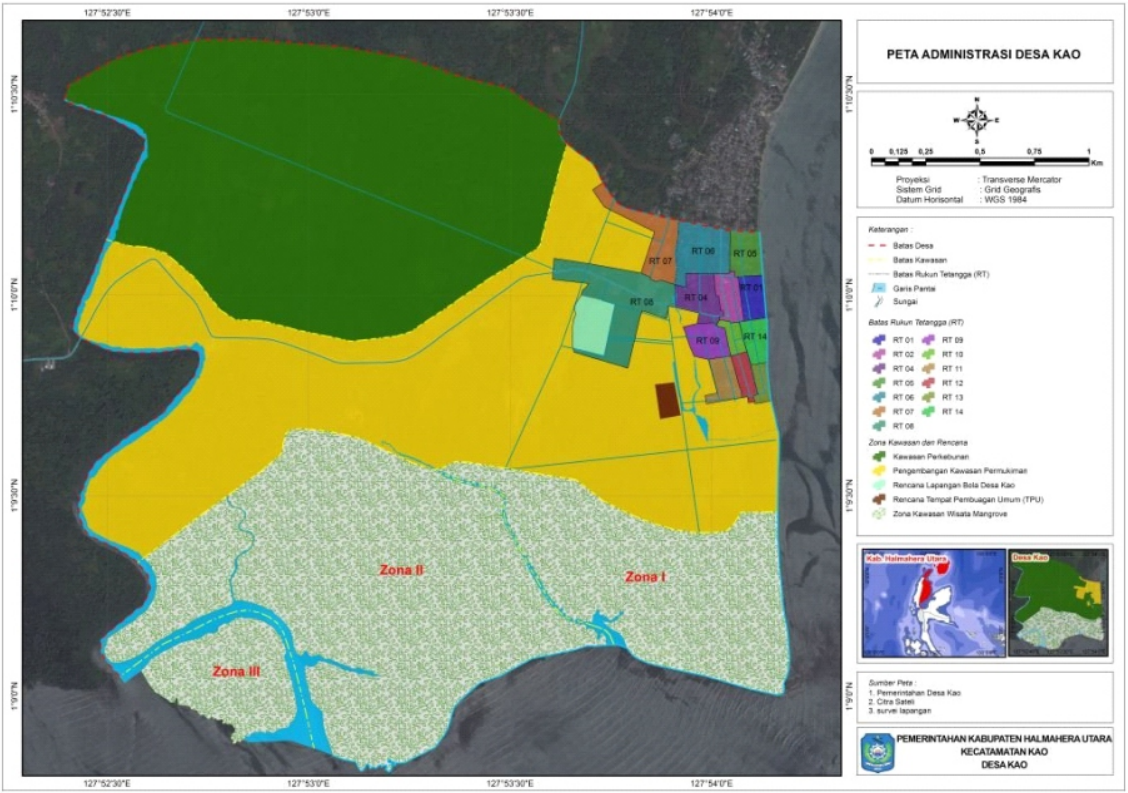

(Source: The Government of North Halmahera District)

Figure 2 Map of Kao Village. 
shellfish (Pilsbryoconcha exilis), eels (Monopterus aibus), shrimp (Caridea) and even the eggs of mamoa bird (Eulipoa wallacei). Besides, the habitat of fruit bats (Cynopterus brachyotis) in the mangrove forest area is also a hunting ground for local people to consume. Local people also consume sabeta (Rhynchophorus ferrugineus) from sago trees (Metroxylon sagu), which can be found along the river bank. The availability of natural resources, especially forest resources, can be accessed by local people without ignoring the cultural values that have been passed down by the ancestors. The people of Kao Village have a tradition of cooperation, known as Higaro and Hirono.

Through the Hirono cooperation tradition, mobility of access to forest resources can be communally optimized, for instance, the cutting down of forests for timber production, which is carried out together as a form of cultural solidarity in helping fellow villagers to establish new settlements. Strengthening the traditional values and customs of the people of Kao Village also regulates patterns and behavior in social interactions so that they humanize one another. The origin of the philosophy of Kao's identity as a social bonding (Towiliko) is the embodiment of noble solidarity values as local wisdom. The need for resource consumption associated with the number of Kao's community populations. The higher number of people, the higher demand for resource consumption The common livelihood strategies of Kao's community supported by fishing and farming activities. As for agricultural products and fish products, besides being marketed, they are also consumed daily. The indigenous people hold a ritual to protect the area that residents may not use within a specified period. The ceremony is known as Sasi, which symbolically has a material form of culture (Matakao) and is spiritually believed to have the ability to punish every act of violation. It is known as the traditional conservation method, which has changed in shape since the introduction of religious teachings and government policies regarding conservation areas.

Culture has become the identity of Kao people with various rituals whose existence serves as a social glue and raises awareness to preserve the environment. Culture mobilizes Kao Village people's access capability to social and natural capital. On the other hand, as an Indonesian citizen, the state law binds social behavior and collective action of the people in Kao Village. The dominance of the state system, structurally through various policies and institutions, actually limits the space for customary institutions through bureaucratic and administrative procedural matters. Due to Kao's livelihood structure and function, there has been an inductive conversion and modification associated with the state government system.

In the context of culture, the function of Kimalaha is very complicated because it must maintain villager's security and regulate social patterns and behavior with various customary rules that apply under the Higaro context. The term and function of Kimalaha have also changed since the annexation of Ternate Sultanate power through the spread of Islam ideology and altered the structure and function of local custom institutions into Sangaji, Fanyira, Jo Hukum, and Samangau. Furthermore, the enactment of regional and village government systems also changed local custom institutions' function and structure into bureaucratic and administrative arrangements in village government structures.

The dominance of the local government bureaucratic system through various policies and institutions to regulate the patterns and behavior of social interaction is contradictory to the traditions of Higaro and Hirono as a representation of Kao's active solidarity without administrative obstacles. However, the local government system's adoption up to the village level is considered capable of mobilizing the Kao Village community's access capabilities to other forms of capital, such as financial capital, physical capital, and human capital. During the transition from cultural to structural change, the term leader in adat institutions known as Kimalaha changed to become the Village Head. Likewise, the function of the leadership structure in adat institutions that is more comprehensive has altered according to the village government's construction with the necessary tasks and responsibilities stipulated by the Law.

Based on the primary data collected by in-depth interviews with the Head of Kao Village, cultural aspects integrated with structural elements enhance rural development. Taufik Max, as a Head of the Kao Village, stressed that "policy and institutions" were the main factors driving local economics's acceleration. Furthermore, policies regarding the use of mangrove forest resources must be supported institutionally under the community-base ecotourism approach. Local community who is interested in improving the economy through the ecotourism approach can participate actively through the Kao Village Tourism Awareness Group (Pokdarwis).

Policies and institutions in Kao Village for tourism development programs are integrated with seven charm known as Sapta Pesona (security, order, cleanliness, coolness, beauty, friendliness, and memories). The plan has been implemented in the construction of waste processing sites, controlling livestock raising, community protection training, mangroves nursery (Bruguiera ciliyndrica), cleaning of coastal areas, and protected animal campaign. The policy is also institutionally supported by the establishment of a Tourism Awareness Group (Kelompok Sadar Wisata) and integration with family welfare groups (Pembinaan Kesejahteraan Keluarga), adat and religiousbased groups. In addition, several collaborative training organized by the local government is implemented to raise public awareness to protect mangrove forests as the following documentation.

Figure 3 It is a documentation of the process of mangrove seedling (Bruguiera ciliyndrica) by the villagers of Kao Village as a form of environmental awareness. Mangrove seedling of the villager is an effort to achieve sustainable mangrove forest for sustainable ecotourism. Efforts to preserve the environment are supported by local government policies, institutions, and the Kao Village community's culture. The expansion of Ternate Sultanate power in the old site of Kao (Kampung Tua Kao) caused assimilation. Since the Kao's community decide to be apart of Islam Believers, convergence between local tradition and religion manifested in the rite of Tagi Jere. Tagi Jere ritual also stimulates the habitus for the pilgrimage activity by visiting the tomb of Shaykh Al Mansyur, annually. The Kao community upholds 


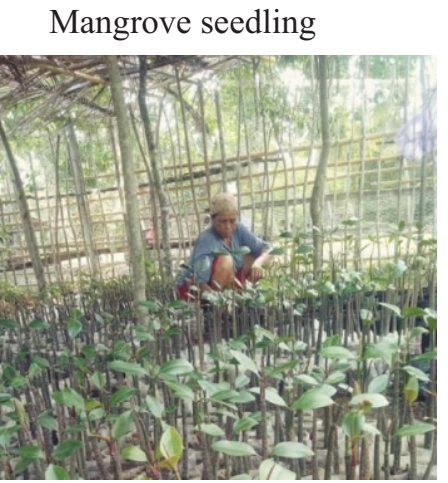

Mangrove zone in Kao Village

Source: Kao Village Government and AMAN Institution

Figure 3 Mangrove seedling (Bruguiera ciliyndrica).

the noble values that are inherited to maintain the relationship between humans and the Ultimate Concern, human relationships with others, and human relations with nature.

The local livelihoods supported by fishing activities, farming, and trading. Based on the primary data, it is known that the Kao villagers' coping strategies depend on various vulnerability contexts such as climate problems (dry, rainy, and windy seasons) that cause crop failure or obstructed fishing activities. Livelihood diversification is stimulated by the availability of resources and the capability to access the capitals. For example, local fishers rent out traditional boats (Ketinting) to tourists visit the mangrove forest through the coast area. On the other hand, farmers process the plantation products and sell it to tourists who visit the mangrove forest in Kao Village. The Intensification and Diversification of local livelihoods can improve the family's economy and then mobilize children's access capabilities to education. Thus, policies and institutions for the utilization of mangrove forest resources mobilize capacity for access to forms of financial capital, human capital, and physical capital.

On the other hand, the existence of PT. Nusa Halmahera Minerals (NHM), in the traditional territory of the Hibualamo community, carries the risk of environmental damage. Nevertheless, the Social Performance program in the field of Corporate Social Responsibility (CSR) of PT. NHM intensively assists the government of Kao Village in human resource development (formal and informal). PT. NHM collaborates with local government to give scholarships for students from Kao. PT.NHM also work with professional agriculture trainer from Hobata farm to held training programs for Kao Sub-District to improve farmers' livelihoods and agricultural products. In addition, PT. NHM also collaborate with local government to build public facilities and infrastructure. It is known that the government and the private sector also mobilized the capability of community access to financial capital, human capital, and physical capital, as the results of interviews with Edy Papilaya, Taufik Max, and Melky Laranga.

In the dynamics of village development, the Kao people's livelihood trajectory shows a change in the structure of social capital based on a sustainable livelihood approach perspective. Therefore, the discussion in this article will accurately analyze several things as follows: First, the livelihood and cultural background of the Kao community. Second, forest management through community-based ecotourism Third, reflection on contextual development including the theoretical and empirical significance that illustrate the researcher's position in reconstructing ideas and building arguments against the dynamics of the Kao Village community livelihoods.

Livelihood and cultural background of Kao community The Kao Village community was part of the Hibualamo cultural group known as Towiliko or Hoana Towiliko tribe. The people in North Halmahera's cultural history showed that the ancestors of each tribe on the North Halmahera mainland came from Telaga Lina, which is located in the Halmahera forest (Nur, 2018). The exodus or permanent migration from the interior to the coastal area was a decision made collectively by each family (soa) known as Soa Modole, Soa Pagu, Soa Boeng, Soa Towiliko, Soa Mordina, Soa Morodai, Soa Lina, Soa Gura, Soa Fea, Soa Fea Mumulati, and Soa Huboto (Platenkamp, 1993). Each family (soa) was developed into a larger family group, so-called tribe (Hoana) "(Handoko \& Mujabuddawat, 2017). Every family had the right to acquire land that had been pioneered as a place for settlement or private plantation land. Land ownership was recognized traditionally based on shared norms (Duncan, 2001). As a form of strong brotherhood and kinship, the process of pioneering land was not done alone but together based on local traditions referred to as hirono or makiriwo (Kotalaha \& Sasongko, 2018). The geographical context of each residential area of the hoana could be classified based on the characteristics of the coastal, inland, and archipelagic regions. The results of adaptation to the conditions of the natural environment caused a modification of habitus represented in traditions and rituals, as well as in harvesting crops, weddings, funerals, fishing, making boats, purifying settlements, and protecting plantation land "(Platenkamp, 1990; Regel et al., 2019). Several residential areas on the North Halmahera mainland had experienced acculturation and assimilation along with the annexation of the power of the Sultan of Ternate (Handoko, 2017; Handoko et al., 2018). Previous research illustrated that the Kao Village community livelihood sustainability was supported by the traditions and culture of Hibualamo, which allowed 
each family to obtain land for plantations and settlement purposes.

The efforts to maintain the sustainability of livelihoods as farmers and fishers had been carried out by the Kao Village community since the decision to settle in the coastal area. The traditions of the Hoana Towiliko customary community continued periodically to be held as mandated by the ancestors to strengthen the brotherly relations between individuals in the family ( $s o a$ ), and between families within one tribe (Hoana). As the development of the teachings of Islam and Christianity in North Halmahera, there were shifts and changes in the ideology of tribal societies following the religious values adopted(Muhammad, 2018; Duan, 2019). In the context of protection of forest resources or plantation land, the changes that occurred can be described as in Table 1.

Table 1 illustrates that the local community's knowledge and practice in protecting forest and plantation land resources'sustainability had shifted due to acculturation, assimilation and legal intervention through state law. From the perspective of sustainable livelihood, the experts did not necessarily describe the modification of livelihood structures in terms of access to natural and social capital. Adjustment on livelihood structure in Kao's community represents an adaptation due to several issues such as acculturation, and assimilation, or legal intervention. This case shows a gap in the previous conceptual framework of sustainable livelihood constructed by international development agencies (ODI, 1991; Stern et al., 2012). Nevertheless, Robert John Haylock Chambers and Richard Gordon Conway illustrated how communities in rural areas could access resources in the form of capital to maintain their livelihoods(Chambers \& Conway, 1992).

The influence of the sultanate power stimulates assimilation issues and livelihood changes in Kao's community (Handoko et al., 2018; Mulae, 2016). Also, the activity of Nederlandse Zending Vereniging in Halmahera cause acculturation issue "(Parker, 2003). Religious activities were slowly shifting the local community's paradigm concerning the communication patterns and social interactions under spiritual teachings. However, it did not necessarily limit the access to social capital but slightly changed the structure in traditional communication patterns (Higaro) to the ones that were following their religious teachings (Din, 2019). In other regional contexts, the impact of traditional communication pattern shifts - that uphold collectivity and togetherness into a closed pattern of communication-based on religious teachings - might lead to social segregation, which at times could lead to conflicts on theological issues (Humaedi, 2014; Rubawati, 2018). Religion and culture have an essential role in driving the socio-cultural action of Kao's community. Kao's society well known as Hoana Towiliko, which means to unify (binding all tribes in Hibualamo). Kao's village also has Tagi Jere rite as the form of assimilation between culture and religion (Manan, 2014). As time passed, Kao village community's language and culture had adjusted(Retnowati, 2014).

The Kao people not only depend on cultural-based ideology but also consider religious aspects and bureaucratic systems, policies, and laws in accessing natural capital and social capital. Based on the primary data, culture-based forest protection known as Bubugo, Matakao has transformed into religious-based forest protection known as Sasi or have changed to conservation method as stipulated in the forest protection law, such as Essential Ecosystem Area (Kawasan Ekosistem Esensial (KEE). The transformation methods of protecting natural resources have led to the modification of livelihood structures that are primarily related to the capability to access natural and social capital. The change of livelihood structure related to the ability to access natural and social capital can be seen in Figure 3. below.

Figure 4 picturizes the context of traditional knowledge and practices in the process of accumulation of natural and social capital that experienced changes (modification) after the annexation of the power of the Sultan of Ternate, the spread of the teachings of Islam and Christianity, as well as the application of both centralized and decentralized government system which set boundaries in administrative areas and rules on the use of natural resources in accordance with policies or laws applicable in Indonesia. Thus, it could be seen that the Higaro tradition authentically mobilized the capability of access to the natural and social capital of the Kao Village community. In its development, the accumulation of natural and social capital was developed with different stimuli.

The modification of Kao's community livelihood structure could encourage the intensification and diversification of forms of capital. It could be used to access the financial, human, and physical capital, as illustrated in the conceptual framework of sustainable livelihoods (Ashley

Table 1 The effort to protect natural resources

\begin{tabular}{lll}
\hline $\begin{array}{c}\text { Bubugo or Mata Kao } \\
\text { (Authentic/Traditional) }\end{array}$ & Sasi (Acculturation/Assimilation) & Conservation (State Law) \\
\hline $\begin{array}{l}\text { Based on local tradition, Bubugo or } \\
\text { Mata Kao was a cultural symbol }\end{array}$ & $\begin{array}{l}\text { The shift of local cultural values due to the } \\
\text { inclusion of religious ideology led to the }\end{array}$ & $\begin{array}{l}\text { Protection of forest areas and marine } \\
\text { resources in the concept of conservation }\end{array}$ \\
traditionally as a form of artistic & convergence of spiritual teachings with & was a policy product of the government \\
communication to tell everyone that the & local culture in the processing of forest & system in Indonesia as an effort to \\
tree or plantation area had been own and & resources. The installation ritual of Mata & prevent environmental exploitation that \\
protected by the spirit so that the tree & Kao was considered wrong and in contrast & exceed the carrying capacity and \\
nor the fruits could be cut down or & to the religious teachings. Sasi is a & caused instability in the economic, \\
taken. Anyone violating the rules would & convergence of religion and cultural & social, and cultural aspects of local \\
be subject to sanctions in the form of & symbol used to protect plantations or & communities. \\
psychological and physical illness or & forests with a cross marked as a sign that & \\
even death. & the area is restricted without permission. &
\end{tabular}

Source: Results of empirical data processing 


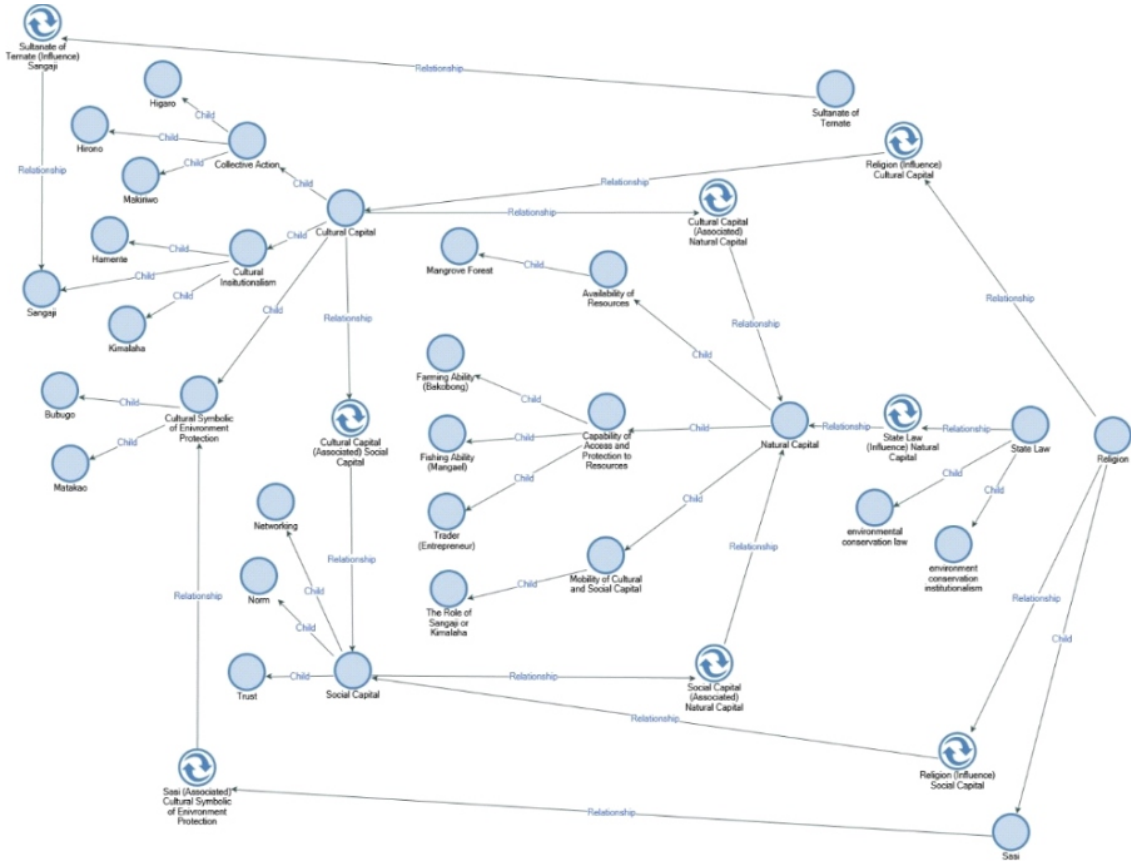

Source: Result of primary data processing using Nvivo 12 Plus application.

Figure 4 Livelihood structure of the Kao Village community in accessing natural capital.

\& Carney, 1999). However, it might limit the capability of access to previously obtained capital, such as the policies and institutions supporting the mining sector operations in the common area of Hoana Towiliko as a means for mobilizing access to forms of the financial, human and physical capital (Sulaksono, 2015). It did limit the community access to natural capital that was previously obtained due to environmental damage (Simbolon et al., 2010). The policies and institutions should mobilize the Kao Village community's capability to access all forms of financial, human, and physical capital through development approaches in the environmentally friendly sector, which also favored economically and had fewer risks of social conflicts.

Forest management through community based ecotourism The forest resource management through a community-based ecotourism approach was an environmentally friendly, socially, and economically beneficial development strategy for rural areas (Manaf et al., 2018). The ecotourism concept emphasized environmental sustainability so that the development orientation of tourist objects was not intended for mass tourism (Pegas et al., 2013). The forest resources had been manage into plantations and agriculture. The Kao Village community also strived to maintain the mangrove forests to be developed as tourism objects through the concept of community-based ecotourism. The advantage of developing community-based ecotourism was providing opportunities for equal income distribution with minimum risk of environmental damage. Thus, it could improve community welfare through economic independence at the village level (Snyder \& Sulle, 2011; Sakata \& Prideaux, 2013).
Around the residential area of Kao Village, there was a mangrove forest area of 404 hectares. The river flowing between the mangrove vegetation and the coastal area was the location of the sea turtle (Chelonia mydas) and Gosong Maluku (Eulipoa wallacei) endemic birds eggs. It simultaneously encouraged the Head of Natural Resource Conservation Center (Balai Konservasi Sumber Daya Alam (BKSDA)) of Maluku to also encourage the Kao Village area into an Essential Ecosystem Area (Kawasan Ekosistem Esensial (KEE)). Nevertheless, people often cut down the mangrove tree for household purposes. In 2017, the Kao's village government tried to formulate regulations on environmental preservation. Several programs conducted to disseminate the importance of mangroves for ecosystem sustainability. Collaborative training to manage mangrove and wildlife also held in Kao Village, which was attended by various stakeholders such as Regional Tourism Official, Academicians, and multiple stakeholders. The efforts to ensure environmental sustainability was one of the village development programs. The village government had also proposed that the protection of mangrove forests should also provide economic benefits for the livelihoods of the Kao Village community through the development of ecotourism.

The ecotourism approach was used as a basic concept of mangrove forest management that could benefit the local community in terms of economic, socio-cultural, and environmental aspects. This case indicated that the ecotourism approach in the development of Kao Village was an effort to change the community's dependence on the mining sector. The tourism sector was considered as the right approach considering environmental, social, and economic sustainability (Stronza, 2011). Ecotourism in Kao Village is still in the initial stages of development, the interest of 
tourists who come to the Mangrove Forest area is to observe the scenery. The visitors who come to the village have interests in photography and pilgrimage. The community gain benefits from transportation services and guide services to visitors. In terms of quantity, the number of visitors is unpredictable. Saputra \& Setiawan (2014) said that The tourist could do various activities such as photography, swimming, bird control, canoeing along the mangrove forest and fishing from the ecotourism development.

The development of ecotourism was also one of the educational efforts on conservation areas to increase environmental awareness (Wijayanti, 2009). The implementation of the ecotourism approach in Kao village has raised public awareness about the importance of ecological sustainability. This case can be seen from the reduction in waste disposal behavior and a better livestock raising system. The ecotourism approach is a stimulus for public awareness for the capabilities of future generations to access natural resources. The ecotourism concept was becoming more popular in Indonesia because it balanced the environmental, economic, and social aspects (Fahrian et al., 2015). Besides, it was also adopted as an approach to rural tourism development (Prasetyo \& Suwandono, 2014). This case showed that it brought economic benefits for the community, especially in rural areas in the context of coastal regions and watersheds.

The mangrove tourism development would maintain the natural environment around the settlements compared to the mining sector, which tended to be exploitative (Wijayanto et al., 2013). The mining industry activities around the Kao Village community's common area also caused river pollution, emptied into Kao Bay (Edward, 2019). The river pollution caused contamination on the animals commonly consumed by the Kao Village community in the waters of the Kao bay and around the river area known as anchovies, shellfishes, and freshwater shrimps (Samman et al., 2014; Pertiwi, 2018). This case proved that the mining sector activities posed a threat to environmental sustainability. Nevertheless, the mining sector, with its corporate social responsibility (CSR) program, tried to encourage development through the assistance of educational costs and infrastructure development support for the economy of the community in Kao Village (Bubala et al., 2015). However, CSR programs will not be able to replace the environmental loss.

The activity of the mining sector had the potential to limit the capacity of access to resources such as natural and social capital. Mining activities had a high risk of ecological loss and contaminate land or stream as livelihood assets of Kao's community. The environmental damage and limited access to plantation land had the potential to create conflicts that limited access to social capital. Nevertheless, the mining industry's existence with its CSR program was able to mobilize the capability of community access to human capital through the support of education costs and physical capital through the construction of supporting infrastructures such as roads and bridges. This case showed that the mining sector had a negative impact as well as positive benefits. The mining sector operations could not be stopped because they were bound by policies and institutions of the public sector (local government). Nevertheless, the village government began developing the village's tourism sector as a sustainable development approach. The Kao Village community was also starting to realize the importance of natural and social capital that had been passed down by ancestors through tradition such as Tagi Jere, which was held annually '(Manan, 2014).

Sustainable livelihood in rural development: Reflection on contextual development Reflection on contextual development linked the description of the previous topic by emphasizing the theoretical significance in the case of the Kao Village community livelihood. Based on this case, it could be seen that the local culture or traditions could mobilize the capability of access to natural and social capital. In various development dynamics, the community still had the ability to access to natural and social capital, although it was in a different form of structure. Contextually, this indicated the availability of resources as assets (capital) that could be optimized by the community for livelihood sustainability. The Kao Village community utilized their natural and social capital under the norms applied in their local traditions and culture. Thus, the key to sustainable livelihoods was in the capability of access (Chambers \& Conway, 1992).

From the perspective of sustainable livelihood, the capability of access to various forms of capital was influenced by the context of vulnerability, such as shock, trend, and seasonality, which were contextual in nature "(Ashley \& Carney, 1999). Along with the mining activities in the Kao Village community's customary area, there was a shock caused by environmental damage that threatened the capability of Kao Village community access to natural and social capital. Although mining activities are not close to residential areas, contamination of mining waste into the river flow affects the bay's environment. Pollution in the Kao bay limits fisher's access to their activities, so they must travel a considerable distance to catch fish. On the other hand, the mining companies with their CSR program were able to mobilize the Kao Village community's capability to access human and physical capital as a consequence of optimizing natural resources through the mining sector. The mining sector's existence as part of the development approach was inseparable from the policies and institutions determined by the local government. This case also shows that the policies and institutions played an essential role in the structure of sustainable livelihoods(Ellis, 1998).

The accumulation of natural, social, human, and physical capital drove the Kao Village community's awareness of environment, socio-culture, and economic sustainability. Therefore, the decision to optimize natural resources, especially the mangrove forests as tourism objects, was the most appropriate way to access financial capital. This case showed that the Kao Village community, through the village government, used the ecotourism approach to accumulate all forms of capital that supported the sustainability of livelihoods. The utilization of natural resources through the concept of ecotourism could stimulate several actions to endurance livelihood sustainability. Recent studies discuss several issues on livelihood security through intensification, extensification, and diversification (Kim \& Ellis, 2015). The 
previous research also states that a community-based ecotourism approach can increase the community's living standard (Snyder \& Sulle, 2011). The implementation of community-based ecotourism facilitates local community ideas to utilizing natural resources as a tourism attraction. (Arnegger et al., 2010). The ecotourism concept was used as a development concept that was contextual and relevant to developing country conditions (López-Bonilla \& LópezBonilla, 2012).

The reflection of contextual development for community livelihoods in Kao Village was essential to be developed as a policy recommendation, considering the community limitations in intervening in the operations of the mining sector. As policymakers and development providers, the local government should consider the long-term development and consequences of mining industry activities for the sustainability of community livelihoods. However, the development orientation should be in favor of the community rather than the economic growth and regional investment, which ultimately limited the ability of community access to various forms of capital. This study indicates that the ecotourism approach is the right approach in developing with less environmental damage than the mining industry. Therefore multiple policies and institutions should support the concept of ecotourism.

This study's results indicate that the utilization of mangrove forests through community-based ecotourism enhances the sustainable livelihood of Kao Village. Based on the form of capital in livelihood perspective, the capability to access to natural and social capital was supported by local tradition known as Higaro. In other words, livelihood and cultural background integrated to maintain sustainability. Communal patterns of social interaction in Kao's culture enhance the community's capability to optimize natural resources. Therefore, the optimization of mangrove forest resources through a community-based ecotourism approach is relevant. In addition, the capability to access natural capital no longer depends on cultural aspects but also structural aspects. This can be observed from the change in cultural conservation methods from bubugo or matakao into a cultural-religious conservation method known as sasi until structural conservation method according to protection and management of the environmental regulation. The modification livelihood structure of Kao's community occurs with several moments, start from the annexation of the Ternate sultanate until the bureaucracy improvement with various regulations. This article concern about the influence of mining sectors on Kao's people's livelihood structure modification. The mining industry causes environmental loss by contaminates natural resources, which is consumed by Kao's people. It also limits the capability of Kao's community to access natural resources, especially fishermen. However, Corporate Social Responsibility (CSR) programs from the mining sector cannot offset environmental losses. Environmental damage from the mining sector has become a stimulus for Kao villagers to adopt environmentally friendly rural development approaches. Thus, the Kao's village government and villagers start to utilize the mangrove forest for sustainable livelihood through community-based ecotourism.

\section{Conclusion}

This study's results indicate that the utilization of mangrove forests through community-based ecotourism enhances the sustainable livelihood of Kao Village. Based on the form of capital in livelihood perspective, the capability to access to natural and social capital was supported by local tradition known as Higaro. In other words, livelihood and cultural background integrated to maintain sustainability. Communal patterns of social interaction in Kao's culture enhance the community's capability to optimize natural resources. Therefore, the optimization of mangrove forest resources through a community-based ecotourism approach is relevant. In addition, the capability to access natural capital no longer depends on cultural aspects but also structural aspects. This can be observed from the change in cultural conservation methods from bubugo or matakao into a cultural-religious conservation method known as sasi until structural conservation method according to protection and management of the environmental regulation. The modification livelihood structure of Kao's community occurs with several moments, start from the annexation of the Ternate sultanate until the bureaucracy improvement with various regulations. This article concern about the influence of mining sectors on Kao's people's livelihood structure modification. The mining industry causes environmental loss by contaminates natural resources, which is consumed by Kao's people. It also limits the capability of Kao's community to access natural resources, especially fishermen. However, Corporate Social Responsibility (CSR) programs from the mining sector cannot offset environmental losses. Environmental damage from the mining sector has become a stimulus for Kao villagers to adopt environmentally friendly rural development approaches. Thus, the Kao's village government and villagers start to utilize the mangrove forest for sustainable livelihood through community-based ecotourism.

\section{Recommendation}

Recommendations based on the results of this study are for the government at the village and regional level to issue policies on forest and marine resource processing using the community-based ecotourism approach. The village and regional government should establish funding institutions for the local community who are able to develop the forest and marine resources to accelerate economic development, especially for business characteristics relevant to the ecotourism approach. Thus, the Kao Village community is no longer dependent on the CSR fund by PT Nusa Halmahera Minerals to develop the village, but are able to achieve development goals that improve the welfare in the economic field, maintain the cultural values of Hoana Towiliko for environmental sustainability independently.

\section{Acknowledgment}

The researcher would like to express gratitude to all parties contributing to the research writing. The researcher's deepest gratitude goes to the Head of Hospitality and Tourism Management Department of Faculty of Business Administration and Communication Science, Atma Jaya 
Catholic University of Indonesia, LLDIKTI III, for the publication of financial support in 2020 .

\section{References}

Anani, K. (1999). Sustainable governance of livelihoods in rural Africa: A place-based response to globalism in Africa. Development, 42, 57-63. https://doi.org/10. 1057/palgrave.development.1110037

Ancok, D. (2003). Modal sosial dan kualitas masyarakat. Psikologika: Jurnal Pemikiran dan Penelitian Psikologi, 15(8), 4-14. https://doi.org/10.20885/psikologika. vol8.iss 15.art1

Arnegger, J., Woltering, M., \& Job, H. (2010). Toward a product-based typology for nature-based tourism: A conceptual framework. Journal of Sustainable Tourism, 18(7), 915-928. https://doi.org/10.1080/09669582. 2010.485680

Ashley, C., \& Carney, D. (1999). Sustainable livelihoods: Lessons from early experience. London: Department for International Development.

Astuti, E. W., Hidayat, A., \& Nurrochmat, D. R. (2020). Community forest scheme: Measuring impact in livelihood Case Study Lombok Tengah Regency, West Nusa Tenggara Province. Jurnal Manajemen Hutan Tropika, 26(1), 52-58. https://doi.org/10.7226/ jtfm.26.1.52

Aziz, M. (2014). The model of traditional gold mining and its environmental management in The Paningkaban Village, Gumelar District, Banyumas Regency, Central Java. Dinamika Rekayasa, 10, 20-28.

Ballantyne, M., \& Pickering, C. (2012). Ecotourism as a threatening process for wild orchids. Journal of Ecotourism, 11(1), 34-47. https://doi.org/10.1080/1472 4049.2011.628398

Banerjee, A. (2012). Is wildlife tourism benefiting Indian protected areas? A survey. Current Issues in Tourism, 15(3), 211-227. https://doi.org/10.1080/13683500. 2011.599367

Brata, I. B. (2016). Kearifan budaya lokal perekat identitas bangsa. Jurnal Bakti Saraswati, 5(1), 9-16. https://doi.org/10.1007/s11104-008-9614-4

Bubala, E., Pesoth, F. W., \& Kiyai, B. (2015). Implementasi corporate social responsibility (CSR) PT. Nusa Halmahera Minerals dalam pemberdayaan pendidikan di Kecamatan Kao Kabupaten Halmahera Utara. Jurnal Administrasi Publik, 4(32), 1-7. https://doi.org/10.1017/ CBO9781107415324.004

Chambers, R., \& Conway, G. R. (1992). Sustainable rural livelihoods: Practical concepts for the 21st century. IDS Discussion Paper 296.

Din, M. A. . (2019). Transformasi hibualamo dalam pembangunan keagamaan di Maluku Utara, perspektif komunikasi antaragama. Al-Tadabbur: Kajian Sosial, Peradaban dan Agama, 5(1), 1-13.

Duan, J. E. (2019). Gikiri Moi: Konsep tuhan orang Tobelo dan pengaruhnya terhadap pemahaman iman Kristen. Hibualamo, 3(2), 45-50.

Duncan, C. R. (2001). Savage imagery: (Mis)representations of the forest tobelo of Indonesia. Asia Pacific Journal of Anthropology, 2(1), 45-62. https://doi.org/10.1080/ 14442210110001706035

Edward. (2019). Pengamatan kadar logam berat merkuri $(\mathrm{Hg})$ dan tembaga $(\mathrm{Cu})$ pada daging ikan di Teluk Kao, Halmahera. Junral Pro-Life, 6(2), 122-135.

Eilenberg, M., \& Wadley, R. L. (2009). Borderland livelihood strategies: Thsocioeconomicic significance of ethnicity in cross-border labour migration, West Kalimantan, Indonesia. Asia Pacific Viewpoint, 50(1), 58-73. https://doi.org/10.1111/j.1467-8373.2009.01381. $\mathrm{x}$

Ellis, F. (1998). Household strategies and rural livelihood diversification. Journal of Development Studies, 35(1), 1-38. https://doi.org/10.1080/00220389808422553

Fahrian, H. H., Putro, S. P., \& Muhammad, F. (2015). Potensi ekowisata di kawasan mangrove, Desa Mororejo, Kabupaten Kendal. Biosaintifika: Journal of Biology \& Biology Education, 7(2), 105-111. https://doi.org/10. 15294/biosaintifika.v7i2.3953

Fauzi, A., \& Oxtavianus, A. (2014). Pengukuran pembangunan berkelanjutan di Indonesia. MIMBAR, Jurnal Sosial dan Pembangunan. https://doi.org/10. 29313/mimbar.v30i1.445

Haboddin, M. (2012). Menguatnya politik identitas di ranah lokal. Journal of Government and Politics, 3(1), 109-126.https://doi.org/10.18196/jgp.2012.0007

Hakim, I. (2014). Dampak kebijakan pertambangan batubara bagi masyarakat Bengkuring Kelurahan Sempaja Selatan Kecamatan Samarinda Utara. Jurnal Ilmu Pemerintahan, 2(2), 1731-1741. Retrieved from http://perpustakaan.unmul.ac.id/ejournal/index.php/ um/article/view/158

Handoko, W. (2017). Ekspansi kekuasaan Islam Kesultanan Ternate di Pesisir Timur Halmahera Utara. Kapata Arkeologi, 13(1), 95. https://doi.org/10.24832/kapata. v13i1.396

Handoko, W., \& Mujabuddawat, M. A. (2017). Situs Kampung Tua Kao: Identitas asal usul dan jejak peradaban Islam di wilayah pedalaman Halmahera Utara. Jurnal Pendidikan dan Kebudayaan, 2(2), 150. https://doi.org/10.24832/jpnk.v2i2.653

Handoko, W., Mujabuddawat, M. Al, \& Whittaker, J. (2018). 
Islamicization strategies in Kao Ancient Village, North Halmahera. Kapata Arkeologi, 14(1), 49-62.

Haribawa, P. A., Avenzora, R., \& Arief, H. (2020). The polarization of orientation on cultural land utilization for ecotourism development amongst the local in Bali Aga of Mount Lesung Region. Jurnal Manajemen Hutan Tropika, 26(1), 21-33. https://doi.org/10.7226/jtfm.26. 1.21

Humaedi, M. A. (2014). Kegagalan akulturasi budaya dan isu agama dalam konflik Lampung. Analisa, 21(2), 149. https://doi.org/10.18784/analisa.v21i02.11

Husen, A. (2016). Perairan Teluk Kao Halmahera Utara. Jurnal Ilmiah Agribisnis dan Prikanan (Agrikan UMMU-Ternate), 9(1), 9-15. Retrieved from www.researchgate.net

Irawan, A. A. (2013). Dampak ekonomi dan sosial aktivitas tambang batubara PT. Tanito Harum bagi Masyarakatdi Kelurahan Loa Tebu Kecamatan Tenggarong. EJournal Ilmu Pemerintahan, 1(1), 45-56. Retrieved from http://perpustakaan.unmul.ac.id/ejournal/index.php/um/ article/view/33/25

Kim, S., \& Ellis, A. (2015). Noodle production and consumption: From agriculture to food tourism in Japan. Tourism Geographies, 17(1), 151-167. https://doi.org/ $10.1080 / 14616688.2014 .978812$

Kotalaha, Y., \& Sasongko, G. (2018). Kearifan lokal "Makiriwo" dalam perspektif sustainable livelihood (Studi kasus petani kelapa Desa Apulea, Kabupaten Halmahera Utara). Jurnal Sosiologi Pedesaan, 6(3), 256-262.

Kustiana, A. F., Harafah, L. O. M., \& Millia, H. (2016). Kondisi sosial ekonomi masyarakat di sekitar pertambangan nikel di Kecamatan Bohodopi Kabupaten Morowali. Jurnal Ekonomi, 1(1), 135-145.

Kusumastuti, A. (2015). Modal sosial dan mekanisme adaptasi masyarakat pedesaan dalam pengelolaan dan pembangunan infrastruktur. MASYARAKAT: Jurnal Sosiologi, 20(1), 82-97. https://doi.org/10.7454/ mjs.v20i1.4740

Leinbach, T. R., \& Watkins, J. F. (1998). Remittances and circulation behavior in the livelihood process: Transmigrant families in South Sumatra, Indonesia. Economic Geography, 74(1), 45-63. https://doi.org/10. 2307/144343

López-Bonilla, J. M., \& López-Bonilla, L. M. (2012). Environmental orientation in tourism: The RTEO scale. Current Issues in Tourism, 15(6), 591-596. https://doi. org/10.1080/13683500.2012.657615

López-Bonilla, J. M., \& López-Bonilla, L. M. (2014). Holistic competence approach in tourism higher education: an exploratory study in Spain. Current Issues in Tourism, 17(4), 312-326. https://doi.org/10.1080/ 13683500.2012 .720248

Manaf, A., Purbasari, N., Damayanti, M., Aprilia, N., \& Astuti, W. (2018). Community-based rural tourism in inter-organizational collaboration: How does it work sustainably? Lessons learned from Nglanggeran Tourism Village, Gunungkidul Regency, Yogyakarta, Indonesia. Sustainability, 10(7). https://doi.org/10.3390/ su10072142

Manan, M. A. (2014). Ritual tagi jere dalam komunitas etnik Kao: Peran lembaga dewan adat dan badan syara' dan perkembangannya. Jurnal Masyarakat \& Budaya, 16(1), 27-50.

Muhammad, A. (2018). Forum komunikasi antar umat beragama (FKAUB) Maluku Utara (Sebuah harapan dalam pemeliharaan hidup rukun dan damai). Al-Qalam, 12(2), 85. https://doi.org/10.31969/alq.v12i2.561

Mulae, O. (2016). Sangaji-Jiko Makolano versi masyarakat adat Kao (Studi pada pelestarian sistem nilai budaya). Jurnal Ilmiah PGSD, 10(2), 86-96.

Mutiara, I. A. (2018). Dampak sosial industri pertambangan marmer di Desa Mangilu Kecamatan Bunguro Kabupaten Pangkep. Phinisi Integration Review, 1(1), 22-28.

Nur, A. M. (2018). Social changes and conflicts in Orang Sekaum in The North Halmahera Peace Zone. Advances in Social Sciences Research Journal, 5(8), 111-119. https://doi.org/10.14738/assrj.58.4922

Nuraeni, Y. (2018). Dampak perkembangan industri pertambangan nikel terhadap kondisi sosial, ekonomi, dan budaya masyarakat. Seminar Nasional Edusaintek (pp. 12-22). Semarang: Universitas Muhammadiyah Semarang

[ODI] Overseas Development Institute. (1991). Annual Report 1991/1992. Nottingham: The Russell Press

Oishi, M., Nishizuka, K., Motoyama, M., \& Ogawa, T. (1979). Studies of DE-020 eye drops. Report 1. Intraocular penetration. Nippon Ganka Gakkai zasshi, 83(5), 405-409. Retrieved from http://www.ncbi.nlm. nih.gov/pubmed/474315

Paradhisa, N. Z. (2012). Konflik kepentingan daerah: Studi kasus sengketa perebutan Gunung Kelud antara Pemerintah Kabupaten Kediri dan Pemerintah Kabupaten Blitar. Jurnal Politik, 2(1), 136-146.

Parker, I. N. (2003). Of religion and identity: A study of values, transformations, and confrontations among the Tobelo of eastern Indonesia.

Pegas, F. D. V., Coghlan, A., Stronza, A., \& Rocha, V. (2013). For love or for money? Investigating the impact of an ecotourism programme on locareside's' assigned values towards sea turtles. Journal of Ecotourism, 12(2), 
90-106. https://doi.org/10.1080/14724049.2013.831099

Pertiwi, R. T. A. (2018). The content of lead, cadmium, cuprum, and zinc in anchovy (Stolephorus sp.) and white shrimps (Penaeus merguensis) in Kao Bay. Aquasains, $6(2), 678-584$.

Platenkamp, J. D. M. (1990). 'The severance of the origin'; A ritual of the Tobelo of North Halmahera. Journal of the Humanities and Social Sciences of Southeast Asia, 146(1), 74-92. https://doi.org/10.1163/2213437990003228

Platenkamp, J. D. M. (1993). Tobelo, Moro, Ternate: The cosmological valorization of historical events. Cakalele, 4(1), 61-90.

Prasetyo, E., \& Suwandono, D. (2014). Konsep desa wisata hutan mangrove di Desa Bedono, Kecamatan Sayung, Kabupaten Demak. Ruang: Jurnal Perencanaan Wilayah Dan Kota, 2(4), 361-370.

Regel, H., Matheosz, J. N., \& Deeng, D. (2019). Upacara adat panen "Padi baru/bira Mahihawu" masyarakat Suku Modole di Desa Bailengit Kecamatan Kao Barat Kabupaten Halmahera Utara. HOLISTIK, Journal of Social and Culture, 12(4), 1-14.

Régnier, P., Neri, B., Scuteri, S., \& Miniati, S. (2008). From emergency relief to livelihood recovery: Lessons learned from post-tsunami experiences in Indonesia and India. Disaster Prevention and Management: An International Journal, 17(3), 410-429. https://doi.org/10.1108/ 09653560810887329

Retnowati, E. (2014). Bahasa dan budaya etnik Kao di era globalisasi: Tinjauan filsafat manusia. Jurnal Pendidikan dan Kebudayaan, 20(3), 406. https://doi.org/10.24832/ jpnk.v20i3.153

Risal, S., Paranoan, D., \& Djaja, S. (2017). Analisis dampak kebijakan pertambangan terhadap kehidupan sosial ekonomi masyarakat di Kelurahan Makroman. Jurnal Administrative Reform (JAR), 1(3), 516-530. https://doi.org/10.30872/JAR.V1I3.482

Rist, L., Feintrenie, L., \& Levang, P. (2010). The livelihood impacts of oil palm: Smallholders in Indonesia. Biodiversity and Conservation, 19(4), 1009-1024. https://doi.org/10.1007/s10531-010-9815-z

Rozi, S. (2006). Merentas jalan panjang perdamaian: Negara \& masyarakat dalam resolusi konflik. Jurnal Penelitain Politik, 3(1), 77-89.

Rubawati, E. (2018). Berita online sebagai instrumen dakwah: Antara profetik dan provokatif. Tasamuh: Jurnal Studi Islam, 10(1), 65-77. https://doi.org/ 10.32489/tasamuh.47

Safi, J. (2017). Konflik komunal: Maluku 19992000. ISTORIA: Jurnal Pendidikan dan Ilmu Sejarah, 13(1). https://doi.org/10.21831/istoria.v13i1.17615

Sakata, H., \& Prideaux, B. (2013). An alternative approach to community-based ecotourism: A bottom-up locally initiated non-monetised project in Papua New Guinea. Journal of Sustainable Tourism, 21(6), 880-899. https://doi.org/10.1080/09669582.2012.756493

Samman, A., Lumban Batu, D., \& Setyobudiandi, I. (2014). Konsentrasi merkuri dan hubungannya dengan indeks kepadatan keong popaco (Telescopium telescopium) di Kao Teluk, Halmahera Utara. DEPIK, 3(2), 128-136. https://doi.org/10.13170/depik.3.2.1471

Saputra, S. E., \& Setiawan, A. (2014). Potensi ekowisata hutan mangrove di Desa Merak Belantung Kecamatan Kalianda Kabupaten Lampung Selatan. Jurnal Sylva Lestari, 2(2), 49-60. https://doi.org/10.23960/js1224960

Sasana, H. (2016). Dampak implementasi desentralisasi fiskal terhadap pertumbuhan ekonomi dan stabilitas harga di provinsi di Indonesia. Media Ekonomi dan Manajemen, 30(1), 59-67. https://doi.org/10.24856/ mem.v30i1.230

Simbolon, D., Maxwel, S., \& Wulandari, S. Y. (2010). Kandungan merkuri dan sianida pada ikan yang tertangkap dari Teluk Kao, Halmahera Utara. Indonesian Journal of Marine Sciences, 15(3), 126-134. https://doi. org/10.14710/ik.ijms.15.3.126-134

Singgalen, Y. A., Sasongko, G., \& Wiloso, P. G. (2019). Ritual capital for rural livelihood and sustainable tourism development in Indonesia. Jurnal Manajemen Hutan Tropika, 25(2), 115-125. https://doi.org/10.7226/ jtfm.25.2.115

Snyder, K. A., \& Sulle, E. B. (2011). Tourism in Maasai communities: A chance to improve livelihoods? Journal of Sustainable Tourism, 19(8), 935-951. https://doi.org/ $10.1080 / 09669582.2011 .579617$

Solesbury, W. (2003). Sustainable livelihoods: A case study of the evolution of DFID policy. London: Overseas Development Institute. Retrieved from https://www.odi.org/sites/odi.org.uk/files/odiassets/publications-opinion-files/172.pdf

Stern, E., Stame, N., Mayne, J., Forss, K., Davies, R., \& Befani, B. (2012). DFID Working Paper 38. Broadening the range of designs and methods for impact evaluations. London: DFID

Stronza, A. L. (2011). Commons management and ecotourism: Ethnographic evicende from the Amazon. International Journal of the Commons, 5(2), 319-339. Retrieved from https://www.jstor.org/stable/26523075

Sukwika, T., Yusuf, D. N., \& Suwandhi, I. (2020). The institutional of local community and stratification of land ownership in surrounding community forests in Bogor. 
Jurnal Manajemen Hutan Tropika, 26(1), 59-71. https://doi.org/10.7226/jtfm.26.1.59

Sulaksono, A. (2015). Pengaruh investasi dan tenaga kerja terhadap PDB sektor pertambangan di Indonesia. Jurnal Ilmiah Ekonomi Bisnis, 20(1), 16-24.

Sulistiowati, R. (2014). Implementasi desentralisasi dan otonomi daerah pada daerah otonomi baru (DOB). Sosiohumaniora, 16(3), 270. https://doi.org/10.24198/ sosiohumaniora.v16i3.5767

Syahra, R. (2003). Modal sosial: Konsep dan aplikasi. Jurnal Masyarakat dan Budaya, 5(1), 1-22. Retrieved from http://www.jurnalmasyarakatdanbudaya.com/index.php /jmb/article/view/256

White, B. N. F. (1991). In the shadow of agriculture: Economic diversification and agrarian change in Java, 1900-1990. ISS working Papers-General Series 18817.
The Hague: International Institute of Social Studies of Erasmus University Rotterdam.

Wijayanti, R., Baiquni, M., \& Harini, R. (2016). Strategi penghidupan berkelanjutan masyarakat berbasis aset di Sub DAS Pusur, DAS Bengawan Solo. Jurnal Wilayah dan Lingkungan, 4(2), 133. https://doi.org/10.14710/ jwl.4.2.133-152

Wijayanti, T. (2009). Konservasi hutan mangrove sebagai wisata pendidikan. Envirotek: Jurnal Ilmiah Teknik Lingkungan, 1(1), 15-25.

Wijayanto, D., Nuriasih, D. M., \& Huda, M. N. (2013). Strategies of mangrove tourism development in Nusa Penida Marine Protected Area. Jurnal Saintek Perikanan, 8(2), 25-32. https://doi.org/10.14710/ijfst.8.2.25-32

Yudhistira, Hidayat, W. K., \& Hidayarto, A. (2011). Kajian dampak kerusakan lingkungan akibat kegiatan Gunung Merapi. Jurnal Ilmu Lingkungan, 9(2), 76-84. 